\title{
Study on "Resource Curse" Based on the Panel Data in Coal Resource-Rich Districts of Inner Mongolia
}

\author{
Yao Hong ${ }^{1}$, Tian Meirong ${ }^{2 *}$, Ma Jianjun ${ }^{1,2}$, She Xinlu ${ }^{3}$, and Gao Jixi ${ }^{4}$ \\ ${ }^{1}$ Lang Fang Normal University, Lang fang 065000, China \\ ${ }^{2}$ Nanjing Institute of Environmental Sciences, Ministry of Ecology and Environment of China, Nanjing 210042, China \\ ${ }^{3}$ Renmin University of China, Beijing 100872, China \\ ${ }^{4}$ Ministry of Ecology and Environment Center for Satellite Application on Ecology and Environment, Beijing 100094, China
}

\begin{abstract}
In order to analyse whether there is "Resource curse" in coal resource-rich district of Inner Mongolia such as Xilinguole, Hulunbeier, Tongliao, Chifeng, Erdos and Wuhai during "Golden ten years" (form 2000 to 2011) of coal, we developed the regression model based on the panel data of coal development intensity, manufacturing investment level, R\&D and education investment level and foreign investment level, and test the "resource curse" effect in a holistic and regional way. The results showed that there exist "Resource curse" effect in Inner Mongolia along with economic development, and the effect gradually enhance. Meanwhile, the most serious "Resource curse" exist in Xilinguole, Hulunbeier, Erdos. The most important ways to weaken the "Resource curse" is industrial diversification and technological innovation. In addition, the basic way to solve or avoid "Resource curse" is strengthening the system construction, improving the government's measures and policies on management and utilization of natural resources.
\end{abstract}

\section{Introduction}

Inner Mongolia autonomous region has a vast territory and abundant coal resources, and the coal resources have been identified to break the trillion ton mark, ranking first in China. From 2000 to 2011, Inner Mongolia's coal output increased nearly tenfold, accounting for $27.8 \%$ of the country's coal output, up from $5.2 \%$. With the rapid development of the coal industry, the total economic volume of Inner Mongolia increased from 172.5 billion Yuan to 1.42 trillion Yuan, and the per capita GDP increased from 7,000 Yuan to 57,500 Yuan. In 2012, coal prices fell sharply heralded the end of the "golden decade" of coal, Resource-enriched areas with coal economy as the pillar should not only face the ecological environment damage caused by coal mining, but also face the social and economic problems such as single economic structure, weak foundation and insufficient investment in human capital [1]. When the academic world lamented the economic miracles of "Inner Mongolia development model" and "Inner Mongolia phenomenon", the propositions that "resource curse" and "Dutch disease" effect had to be faced came back to people's vision.

The concept of "Resource Curse" was put forward by Auty [2] in 1993 when he studied the economic development of mining countries. He found that abundant resources were not sufficient favourable conditions for the economic growth of some countries, but a restriction. In recent years, the phenomenon of "resource curse" received widespread attention of Chinese scholars [3], Liu jia (2009) [4] used the method of co-integration analysis and granger causality test to analyse the relationship between coal consumption and economic growth based on the data of Inner Mongolia autonomous region from 1986 to 2007, the inspection results showed that the economic development of Inner Mongolia autonomous region existed the resource curse. Liu tao [5] studied result showed that the development of the energy industry had formed a "crowding out effect" on the manufacturing industry through the cost mechanism. Chen jiping [6] used the shift-share method to decompose and compare the labour productivity of Inner Mongolia, western China and the whole country since the opening up of the western region, and found that Inner Mongolia had the potential problem of resource curse.

Based on panel data and development economics and Econometrics theory, this paper focused on the analysis of whether the "resource curse" exists in Inner Mongolia coal resource enrichment area during the "golden decade" of coal industry. Through the test and analysis of "resource curse" and the results of difference comparison, the crux of "resource curse" were found out, and the ways to solve or avoid "resource curse" were put forward, which could provide decision-making reference for the sustainable economic development of energy-rich provinces.

\footnotetext{
* Corresponding author: tmr@nies.org
} 


\section{Study area}

Inner Mongolia coal mainly distributed in ordos, xilingol league and hulunbuir. Ordos has 148.2 billion tons of planned reserves, accounting for $57.67 \%$ of the total planned utilization of the whole region. The planned utilization reserves of xilingol league are 49.4 billion tons, accounting for $19.22 \%$ of the total planned utilization of xilingol league. Hulunbuer has 29.4 billion tons of planned reserves, accounting for 11.44 percent of the total planned reserves in the region. The planned utilization reserves of wuhai city are 4.324 billion tons, accounting for $1.68 \%$ of the total planned utilization of the whole region. In terms of raw coal production, in 2011, the raw coal output of tongliao city was 65.6888 million tons, the raw coal output of wuhai city was 33.1693 million tons, and the raw coal output of chifeng city was 32.2606 million tons. The above six cities accounted for $95.03 \%$ of the raw coal output of Inner Mongolia (97961.00 million tons) in that year In this study, six typical coal resource rich areas of ordos city, xilingol city, hulun buir city, tongliao city, wuhai city and chifeng city were selected as research units, taking the prefecture-level union city as the research unit.

\section{Method and Data}

Panel data, also known as parallel data, or time series cross-section data or mixed data, refers to the sample data formed by taking multiple sections on the time series and selecting sample observation values at the same time on these sections. In this study, the panel data of "resource curse" in the coal resource rich area in Inner Mongolia is composed of the cross-section data of the six resource-rich areas in the time series from 2000 to 2012. Each year means one section which included 6 sets of data, and each set include 5 data, Total 390 data.

\section{1 model setting}

Based on existing literature and combined with the actual situation of coal resources in Inner Mongolia, the basic regression model of panel data is established as follows:

$$
y_{i t}=\alpha+\beta \text { Coal }_{i t}+\theta Z_{i t}+\varepsilon_{i t}
$$

Type: $y$ is the explained variable, representing the growth rate of GDP per capita of each city. The calculation formula is $\mathrm{y}_{i t}=\mathrm{GDP}_{i, t} / \mathrm{GDP}_{i, t-1}-1$. Coal refers to the development intensity of Coal resources; $Z$ represents the vector set composed of other control variables; $i$ corresponds to the unit of section in Inner Mongolia; $t$ is the year; $\alpha$ is a constant term; $\beta, \theta$ is the coefficient vector; $\varepsilon$ is the random perturbation term.

To investigate the development of coal resources in Inner Mongolia, we select the development intensity index of coal resources to make the results have strong comparability. The proportion of Coal industrial output value in the total industrial output value of the year is selected as the index of Coal resource development intensity (Coal). Other control variables include manufacturing investment level (Manu), $\mathrm{R}$ \& $\mathrm{D}$ investment in science and technology level $(R d)$, education investment level $(E d u)$, system condition (Inst). In order to avoid cross section hetero scedasticity problem, all variables were treated with natural logarithm. The final regression equation will contain all explanatory variables:

$\ln y_{i t}=\alpha+\beta \ln$ Coal $_{i t}+\theta_{1} \ln$ Manu $_{i t}+\theta_{2} \ln R d_{i t}+\theta_{3} \ln E d u_{i t}$ $+\theta_{3} \ln$ Inst $_{i t}+\varepsilon_{i t}$

$\beta$ is the Coal $_{i t}$ coefficient which reflects the impact of coal resource development intensity on economic development. If the $\beta$ value is significantly positive, it indicates that there is no "resource curse" effect in the sample. If the $\beta$ value is significantly negative, the sample has a "resource curse" effect.

\section{2 variables and data description}

The study chooses related index of time series data of six typical coal resources of Inner Mongolia enrichment region from 2000 to 2012, which from The Inner Mongolia Statistical Yearbook (2001 2013), The Coal Resource Enrichment Region Statistics Yearbook (2001 2013) and Chinese City Statistics Yearbook (2001 2013), each indicator of the regression equation wil take a relative. In this paper we choose $F d i$ which measured by the ratio of actual utilized foreign capital to GDP standing for institutional variables (Inst). Specific measures of these dates are shown in table 1 .

Table 1. Calculation formula of indexes.

\begin{tabular}{|l|l|}
\hline Variable symbol & measure \\
\hline Coal & $\begin{array}{l}\text { Coal industry output value/total } \\
\text { industrial output value }\end{array}$ \\
\hline Manu & $\begin{array}{l}\text { Manufacturing fixed asset } \\
\text { investment/total fixed asset investment }\end{array}$ \\
\hline$R d$ & $\begin{array}{l}\text { Total technology expenses/financial } \\
\text { expenditure }\end{array}$ \\
\hline Edu & $\begin{array}{l}\text { Total educational fund/financial } \\
\text { expenditure }\end{array}$ \\
\hline Fdi & Actual utilized foreign capital/GDP \\
\hline
\end{tabular}

\section{Result and Analysis}

\section{1 co-integration test analysis of variables}

Since the sample of the problem studied is a time series, the stationary of the time series should be considered first. The panel data used in this paper is characterized by fewer cross-sectional units and longer time span. If it is not stationary, the regression result will be a pseudoregression. Unit root test was performed on all variables (table 2). 
Table 2 ADF test of time series

\begin{tabular}{|c|c|c|}
\hline Variable & Prob.** & Stationarity \\
\hline $\ln y_{i t}$ & 0.0211 & No \\
\hline$\triangle \ln y_{i t}$ & 0.0002 & Yes \\
\hline $\ln$ Coalit & 0.0289 & No \\
\hline$\triangle \ln$ Coalit & 0.0023 & Yes \\
\hline $\ln$ Manu & 0.0041 & No \\
\hline$\triangle \ln M a n u$ & 0.0006 & Yes \\
\hline $\ln R d$ & 0.0209 & No \\
\hline$\triangle \ln R d$ & 0.0003 & Yes \\
\hline $\ln E d u$ & 0.4656 & No \\
\hline$\triangle \ln E d u$ & 0.0020 & Yes \\
\hline $\ln F d i$ & 0.0315 & No \\
\hline$\triangle \ln F d i$ & 0.0021 & Yes \\
\hline $\begin{array}{l}\text { Note: } * * *, * *, * \text { are significant at the level of } 1 \%, 5 \% \text {, and } \\
10 \% \text { respectively, calculated by Eviews } 6.0 \text { software. }\end{array}$
\end{tabular}

ADF unit root test (table 2) shows that all variables are monolithic in the next order at the 5\% significant level, which meet several basic requirements of panel data multivariate co-integration test: (1) The single integral order of the explained variable is less than or equal to the single integral order of the explanatory variable; (2) when there are two or more explanatory variables, the single integral order of the explanatory variables should be the same. Multivariate co-integration test was carried out by Pedroni (Engle-Granger based), a common tool for panel co-integration test provided by Eviews 6.0 software (table 3 ).

Table 3 Test results of multivariate panel cointegration based pedroni

\begin{tabular}{|c|c|c|}
\hline Test indicators & Statistic & Probability \\
\hline Panel v-Statistic & 0.5972 & 0.23071 \\
\hline $\begin{array}{c}\text { Panel rho- } \\
\text { Statistic }\end{array}$ & 0.7084 & 0.70291 \\
\hline $\begin{array}{c}\text { Panel PP- } \\
\text { Statistic }\end{array}$ & $-5.0935^{*}$ & 0.00000 \\
\hline $\begin{array}{c}\text { Panel ADF- } \\
\text { Statistic }\end{array}$ & $-3.0757^{*}$ & 0.00036 \\
\hline $\begin{array}{c}\text { Group rho- } \\
\text { Statistic }\end{array}$ & 1.6891 & 0.87090 \\
\hline $\begin{array}{c}\text { Group PP- } \\
\text { Statistic }\end{array}$ & $-4.2194 *$ & 0.00000 \\
\hline $\begin{array}{c}\text { Group ADF- } \\
\text { Statistic }\end{array}$ & $-2.1776^{*}$ & 0.00765 \\
\hline
\end{tabular}

The establishment of multivariate co-integration test is based on the establishment of the null hypothesis that there is a co-integration relationship between variables. We can know that, under the condition of homogeneity test (Assume that all sections have uniform AR coefficients), Panel v-statistic and Panel rho-statistic cannot reject the null hypothesis without cointegration, while Panel PP Statistic and Panel ADF Statistic reject the null hypothesis, holding that all sections have a common AR coefficient, and the coefficient value is less than 1. Under the condition of heterogeneity test (the AR coefficient value of each section is required to be less than 1), the Group rho-statistic cannot reject the null hypothesis, indicating that there is no co-integration relation, while the Group pp-statistic and Group adfstatistic are both significant, indicating the existence of heterogeneous co-integration relation. Therefore, there is long-term stability between the original variables of the equation, and the regression based on the sample data is not a "pseudo-regression".

\section{2 empirical results analysis of "resource curse" in the region}

The panel data regression method and the least square method was used for parameter estimation, the weighted method was section weighted besides. In the analysis, control variables are added gradually in order to gradually observe the influence of each control variable on the correlation effect between coal resource mining intensity and economic growth in coal resource rich areas. By using the Eviews6.0 statistical software, we adopted the ordinary least squares estimation method (OLS) to do regression analysis, according to introduce explanatory variables successively, and carry out White test and D-W test, we found that there was no autocorrelation in the error terms of regression equation. The regression results obtained by using data are shown in table 4.

Table 4 Analysis of regression results

\begin{tabular}{|c|c|c|c|c|c|}
\hline Variable & $\begin{array}{l}\text { Model } \\
1\end{array}$ & $\begin{array}{l}\text { Model } \\
2\end{array}$ & $\begin{array}{l}\text { Model } \\
3\end{array}$ & $\begin{array}{l}\text { Model } \\
4\end{array}$ & $\begin{array}{l}\text { Model } \\
5\end{array}$ \\
\hline $\ln y_{t}$ & $\begin{array}{l}-0.399 \\
(-0.108)\end{array}$ & $\begin{array}{l}-1.508 \\
(-2.70)^{* * * * *}\end{array}$ & $\begin{array}{l}-1.394 \\
(-255)^{* * *}\end{array}$ & $\begin{array}{l}-1.801 \\
(-259)^{* * * *}\end{array}$ & $\begin{array}{l}-1.702 \\
(-260)^{* *}\end{array}$ \\
\hline Coal & $\begin{array}{l}-0.078 \\
(-2132)^{* \alpha * *}\end{array}$ & $\begin{array}{l}-0.049 \\
(-258)^{* * *}\end{array}$ & $\begin{array}{l}-0.041 \\
(-2.44)^{* * *}\end{array}$ & $\begin{array}{l}-0.045 \\
(-252)^{* * *}\end{array}$ & $\begin{array}{l}-0.021 \\
(-260)^{* * *}\end{array}$ \\
\hline Мапи & & $\begin{array}{l}0.213 \\
(7.66)^{* * * * *}\end{array}$ & $\begin{array}{l}0.191 \\
(5.96)^{* * * * *}\end{array}$ & $\begin{array}{l}0.113 \\
(5.73)^{\text {*kak }}\end{array}$ & $\begin{array}{l}0.093 \\
(5.57)^{* * * *}\end{array}$ \\
\hline$F d i$ & & & $\begin{array}{l}0.102 \\
(1.35)^{*}\end{array}$ & $\begin{array}{l}0.099 \\
(1.28)\end{array}$ & $\begin{array}{l}0.092 \\
(1.06)\end{array}$ \\
\hline$R d$ & & & & $\begin{array}{l}0.618 \\
(2.05)^{*}\end{array}$ & $\begin{array}{l}0.512 \\
(1.92)^{*}\end{array}$ \\
\hline$E d u$ & & & & & $\begin{array}{l}0.038 \\
(1.11)\end{array}$ \\
\hline $\begin{array}{c}\text { Constant } \\
\text { term }\end{array}$ & $\begin{array}{l}17.103 \\
(5.11)^{* * * *}\end{array}$ & $\begin{array}{l}18.129 \\
(5.69)^{* * * * *}\end{array}$ & $\begin{array}{l}20.238 \\
(5.06)^{* * * * *}\end{array}$ & $\begin{array}{l}21.003 \\
(4.18)^{* * * *}\end{array}$ & $\begin{array}{l}19.132 \\
(4.02)^{* * *}\end{array}$ \\
\hline $\begin{array}{c}\text { Parametr } \\
\text { ic test }\end{array}$ & $\begin{array}{l}\mathrm{F}=57.06 \\
P>F=0.0 \\
00\end{array}$ & $\begin{array}{l}F=79.87 \\
P>F=0.00 \\
0\end{array}$ & $\begin{array}{l}F=75.73 \\
P>F=0.0 \\
00\end{array}$ & $\begin{array}{l}\mathrm{F}=54.12 \\
\mathrm{P}>\mathrm{F}=0.0 \\
00\end{array}$ & $\begin{array}{l}F=49.87 \\
P>F=0.000\end{array}$ \\
\hline$R^{2}$ & 0.719 & 0.723 & 0.701 & 0.737 & 0.749 \\
\hline
\end{tabular}

Note: The value in square brackets below the coefficient value is the $t$ test value of the coefficient. $* * *$ and $* * *$ respectively indicate that the coefficient has passed the significance test of $10 \%, 5 \%$ and $1 \%$. 
The coefficient of coal mining intensity is about 0.078 (column 1 of table 4 ), and it has a significant negative correlation with economic growth at the level of $1 \%$, however, this is not enough to explain the existence of the "resource curse" effect. As can be seen from the "Dutch disease" effect, the abundant resources in most areas of Inner Mongolia are often invested into the real estate industry and luxury industry in the economically developed regions, which further aggravates the capital shortage of the manufacturing sector in this region, and the economic growth is trapped in a vicious circle. The data in column 2 of table 4 is the result obtained after the introduction of manufacturing input level variable into the model. It can be seen that manufacturing industry is positively correlated with economic growth, while the coefficient of coal mining intensity is still significantly negative at the significant level of 5\%. A good investment environment is an important basic condition for attracting foreign capital. When variables describing institutional conditions with the level of foreign investment are introduced into the model, it can be seen from the results in column 3 of table 4 that foreign investment is positively correlated with economic growth at the significant level of $10 \%$, while the coefficient of coal mining intensity is still negative at the significant level of $5 \%$. The data in column 4 and 5 of table 4 show that science and technology input and education input has a promoting effect on economic growth, but the effect of the former is more significant, while the positive influence of the latter on the economy is not significant. The reason is: Firstly, research and development innovation investment absolute level is low, and the r\&d efficiency is not high, which also has the waste of resources; Secondly, the efficiency of transforming research and innovation achievements into actual production capacity is low, and the market transformation of research and development achievements is low.

\section{3 empirical results analysis of "resource curse" in typical coal resource rich areas}

\subsection{1 "Current Curse" Division of Typical Coal Resource Rich Area}

Based on the research results of Yulong Yao et al. [7], this study uses the resource curse coefficient to illustrate the regional differences of "resource curse" in typical coal-rich areas of Inner Mongolia from 2001 to 2012. The formula as below:

$$
E S_{i}=\frac{E_{i} / \sum_{i=1}^{n} E_{i}}{S I / \sum_{i=1}^{n} S I_{i}}
$$

$E S_{i}$ represents the energy resource curse coefficient of region $\mathrm{i} ; \mathrm{n}$ is the number of regions; $E_{i}$ represents the raw coal production of region i; $S I_{i}$ represents the output value of the secondary industry in region $i$.
The results show that the energy resource curse coefficient can reflect the regional resources superiority and the deviation degree of economic development. If the region accounted for the proportion of raw coal production in the whole area is greater than the proportion of secondary industry output value in the whole area, the regional resource curse coefficient is larger than 1, and the region's resources advantages cannot translate into economic advantage. The resource curse hit the area, and the greater the resource curse coefficient, the more severe the resource curse region suffers. If the resource curse coefficient is less than 1 , the region does not exist the resource curse. The regional differences and variation trends of "resource curse" in coal rich areas of Inner Mongolia from 2001 to 2011 are shown in table 5 .

Table 5 Difference of "Resource curse" index among coal resource-rich regions, Inner Mongolia (2001 2011)

\begin{tabular}{|c|c|c|c|c|c|c|}
\hline Year & $\begin{array}{c}\text { Hulunb } \\
\text { uir }\end{array}$ & Tongliao & Chifeng & Xilingol & Erdos & Wuhai \\
\hline 2011 & 1.3701 & 0.3876 & 0.2336 & 1.4451 & 2.1906 & 0.4930 \\
\hline 2010 & 1.0724 & 0.4783 & 0.2670 & 1.4076 & 1.8517 & 0.5681 \\
\hline 2009 & 1.0738 & 0.6015 & 0.3507 & 1.2277 & 1.6488 & 0.4754 \\
\hline 2008 & 0.9814 & 0.7274 & 0.3552 & 0.9593 & 1.4629 & 0.6059 \\
\hline 2007 & 0.9667 & 0.7971 & 0.4057 & 0.6020 & 1.5270 & 0.6893 \\
\hline 2006 & 0.9561 & 0.8400 & 0.4042 & 0.3823 & 1.5774 & 0.5215 \\
\hline 2005 & 0.8936 & 0.7465 & 0.4335 & 0.2851 & 1.6448 & 0.6031 \\
\hline 2004 & 0.8994 & 0.5664 & 0.4410 & 0.1808 & 1.9991 & 0.5018 \\
\hline 2003 & 0.9349 & 0.4804 & 0.5292 & 0.1629 & 1.7930 & 0.8091 \\
\hline 2002 & 0.8616 & 0.4602 & 0.6227 & 0.1654 & 1.7449 & 0.8679 \\
\hline 2001 & 0.8483 & 0.5584 & 0.6410 & 0.1942 & 1.5194 & 0.8955 \\
\hline
\end{tabular}

It can be seen from the data and its overall change trend in table 5 that the present situation of "resource curse" in the coal resource-rich areas of Inner Mongolia is divided into four forms: (1) the "resource curse" continues to rise (hulunbuir city and xilingol league); (2) "resource curse" continues to decline (chifeng city and wuhai city); (3) "resource curse" fluctuate to decline (tongliao city); (4) "resource curse" abnormally fluctuate to rise (ordos city). Based on the variation trend of "resource curse" coefficients in coal rich areas in recent three years, the division and degree of "resource curse" in coal rich areas in Inner Mongolia are described (table 6).

Table6 Threshold and partition of resources curse

\begin{tabular}{|l|c|c|}
\hline $\begin{array}{c}\text { "Resource curse" } \\
\text { partition }\end{array}$ & $\begin{array}{c}\text { Threshol } \\
\mathrm{d}\end{array}$ & $\begin{array}{c}\text { Partition and degree } \\
\text { ordering }\end{array}$ \\
\hline $\begin{array}{l}\text { "Resource } \\
\text { curse"safety zone }\end{array}$ & $E S i<1$ & $\begin{array}{c}\text { chifeng city }>\text { tongliao } \\
\text { city }>\text { wuhai city }\end{array}$ \\
\hline $\begin{array}{l}\text { "Resource curse" } \\
\text { marginal zone }\end{array}$ & $2>E S_{i} \geq 1$ & $\begin{array}{c}\text { xilingol league }> \\
\text { hulunbuir city }\end{array}$ \\
\hline $\begin{array}{l}\text { "Resource curse" } \\
\text { serious area }\end{array}$ & $4>E S_{i} \geq 2$ & ordos city \\
\hline $\begin{array}{l}\text { "Resource curse" } \\
\text { high-risk area }\end{array}$ & $E S_{i} \geq 4$ & no \\
\hline
\end{tabular}




\section{Conclusion}

Analysis from the perspective of development economics: economic underdevelopment, mineral resources enrichment, economic transition period, these three conditions are consistent with some areas in Inner Mongolia; At the same time, Inner Mongolia began a new industrialization process from the relatively backward economic level in the background of China's economic transformation. The redistribution of various resources, the transformation of government functions and marketization process may produce rent-seeking and official corruption. Therefore, there is the possibility of "resource curse" and other problems in Inner Mongolia's economic growth. Through the panel data analysis of Inner Mongolia, it can be seen from the analysis results including all control variables that the coal mining intensity coefficient $\beta$ is less than zero, and the effect is gradually strengthened, which indicates that Inner Mongolia does have a certain degree of "resource curse" effect. This conclusion is consistent with that of liu jia et al. [8].

Through the empirical study of the relationship between the intensity of economic growth and coal exploitation to six typical coal resources enrichment region, we found that Inner Mongolia coal resources enrichment region "resource curse" status is roughly divided into three partitions: (1) economic transformation experiment site area of enrichment region of coal resources of Inner Mongolia_— wuhai city, chifeng city and tongliao city, which belong to "resource curse" decline zone,namely the safety zone. (2) Inner Mongolia's emerging coal energy base -- hulunbuir city and xilinguolai league, which belong to the "resource curse" continues to rise, namely the marginal zone; (3) Inner Mongolia coal resources core base -- ordos city, which belongs to the "resource curse" abnormally fluctuate to rise zone, namely the serious area.

\section{Discussion}

Problems such as single economic structure, lack of extension space of industrial chain, relatively backward development of manufacturing industry, lack of scientific and technological innovation, insufficient investment in education and limited ability of government to manage resources are common in the coal resource-rich areas of Inner Mongolia. Resources should not be criticized for poor economic growth, however, the policies and measures to manage and utilize them should be improved. For example, China invested 2.27 trillion yuan in the coal industry during the 11th five-year plan period, which formed a huge coal production capacity. After resource integration and technological transformation, mines in major coal-producing provinces and regions came into operation successively, which resulted in huge market surplus pressure. Under the impact of oversupply and foreign coal, the domestic coal price fell all the way in 2012, and the energy economy of most coal-rich areas in Inner Mongolia presented unprecedented difficulties in ten years. This is no doubt that it is related to the excessive investment in the mining industry and the insufficient investment in the manufacturing industry, the management, policies and decisions have greater incentives.

The economic development of Inner Mongolia should be transformed from dependence on natural resources to relying mainly on scientific and technological progress, improvement of labor quality and management innovation, which need to actively improve the level of industrial technology, achieve industrial diversification and gradually reduce the dependence on resources.

\section{References}

1. Bai S.Y., Wu Q., Shen W.S., et al. Land degradation characteristics of grassland mining areas in Inner Mongolia. Journal of Ecology and Rural Environment, 32 (2): 178-186. (2016)

2. Auty R M. Sustaining Development in Mineral Economies: The Resources Curse Thesis. London: Routledge, (1993)

3. Gao J.X., Li Z.F. Phenomenon analysis and Countermeasures of "resource curse". Journal of Ecology and Rural Environment, 29 (1): 1-7. (2013)

4. Liu J. Warning Analysis of Dutch Disease on Inner Mongolia's Economic Development-Co-integration Analysis of Coal Energy Consumption and Economic Growth. Journal of Inner Mongolia Institute of Finance and Economics, 3:103-107. (2009)

5. Liu T., Zhang J.Z., Zhao P.D., et al. Study on the influence of natural resource endowment on industrial structure change - Take Inner Mongolia as an example. Journal of Inner Mongolia University (Philosophy and Social Sciences Edition), (6): 49-54. (2011)

6. Chen J.P. Structural Dividend and Resource Curse Performance Evaluation of Inner Mongolia Industrial Structure Change since the Great Western Development. Resource Development and Market, 28 (12): 1070-1073. (2012)

7. Yao Y.L., Zhou H., Gu S.Z. Analysis of Regional Differences and Driving Forces of China's Resource Curse. Resource Science, 33 (1): 18-24. (2011)

8. $\mathrm{Xu}$ Y.Z., $\mathrm{Hu}$ Y.S. The relationship between economic growth and resource advantage in Inner Mongolia: an empirical analysis based on the "resource curse" hypothesis. Resources Science, 32 (12): 2391-2399. (2010) 